\title{
Just community approach to character education: school change or student change?
}

\author{
Dina Sukma $\left.{ }^{*}\right)$, Azwar Ananda ${ }^{2}$, Nurhizrah Gistituati $^{3}$, Daharnis Daharnis ${ }^{4}$ \\ ${ }^{1234}$ Universitas Negeri Padang, Indonesia \\ *)Corresponding author, $₫$ e-mail: sukmadina@fip.unp.ac.id
}

\begin{abstract}
This article focuses on the development of a strong democracy intervention, the Just Community approach. Three questions framing the discussion include 1) Does Just Community change student or do those in these program change their school? 2) How does Just Community change student and their school? 3) How should democracy be 'learned' by students enrolled to the program? The article begins with a brief history of the Just Community approach, a description of the original developmental model created by Lawrence Kohlberg, and a research carried out in European and US. Just Community's theoretical basis include Piaget's cognitive development theory and Durkheim's view of collective socialization such as how the program is executed and the aim of the program and implementation for education.
\end{abstract}

Keywords: Just community, character education.

How to Cite: Sukma, D., Ananda, A., Gistituati, N., \& Daharnis, D. (2019). Just community approach to character education: school change or student change?. COUNS-EDU: The International Journal of Counseling and Education, 4(1), 15-22. doi:http://dx.doi.org/10.23916/0020190419810

This is an open access article distributed under the Creative Commons 4.0 Attribution License, which permits unrestricted use, distribution, and reproduction in any medium, provided the original work is properly cited. (C2019 by author

\section{Introduction}

Human beings always form groups or communities and depends on each other, developing attachments. Anyone withdrawing from the community often feel alienated, lonely, and face various social problems (Nucci, Krettenauer, \& Narváez, 2014) (Brown et al., 2019).

The community is a collection of individuals who work together to meet the needs of each person. A sense of community is an emotional bond between people which leads to sharing some basics and ensure their needs are met. It is perceived as an individual feeling that it is part of a larger group structure, its community (Sarason, 1974) (Kowasch \& Lippe, 2019).

Just Community is a method of character education which focus to community. Lawrence Kohlberg created this approach because of the dissatisfaction with phenomenal work of "moral discussion". Unlike in the earlier work which focus solely on individual moral reasoning, Just Community emphasizes the culture that affects moral life and discipline takes place in a school. The discipline given in learning institution is based on school culture, referred by John Dewey as the "hidden curriculum"(Wren, 1999) (Kuznetsova, Maksimov, Narozhnaya, Tkachenko, \& Toiskin, 2019). School cultures include the mindset, attitudes and behaviors of students, teachers, principals and other school personnel formed through interactions which are bound by the various rules, norms, morals, and ethics prevailing within the school. Just Community stimulate moral development at a higher stage of children. Generally, children's 
and adolescents are more sensitive to moral issues such as security, justice, honesty, tolerance and space for exspressing moral feelings.

\section{A Brief History of Just Community Approach}

Kohlberg founded the first "School of Community" in the spring of 1974 in the town of Cambridge US. The school produced the a number of principles as follows; the school to be managed with direct democracy, all major issues to be discussed and decided on weekly community meetings where all members (students and teachers) have a voice; there was to be a number of committees filled by students, teachers and parents. Besides, students and teachers were to have the same basic rights, including freedom of expression, respect for others and free from physical or defamatory harm (F C Power \& Higgins, n.d.) (Bates, 2019).

A research was conducted by John Snarey, Joseph Reimer, and Lawrence Kohlberg in 1985 in Israeli schools against 92 teenagers. The participants were divided into urban poor youth groups and local Kibbutz children. For both groups, model of moral education that Kohlberg described as Kibbutz model (later named Just Community) were implemented on two aspects: the regular democratic meeting and the influence of "madrich" , the leader of the community. The results showed significant moral development in both groups (Snarey, Reimer, \& Kohlberg, 1985) (Stichter \& Saunders, 2019).

In 1992, the Just Community model was piloted by Lind and Wolfang in German schools. After one year of Just Community experience, students had the impression that teachers serve them with appreciation, openness and warmth. People were more helpful to each other within the framework of the rules, and students got the opportunity to participate in decision-making. There was also a significant increase in the students' moral reasoning competence(Lind \& Althof, 1992) (Aldridge, 2019).

\section{What is Just Community?}

Just Community is a method of character education by Lawrence Kohlberg which combines moral examples and dilemmas. It emphasizes the interaction of peers and adults with a focus on the culture affecting the moral life and discipline in a community. In this model, the facilitator acts as an adult providing the moral example and discussion necessary to develop the child's ethical reasoning as described in Figure 1

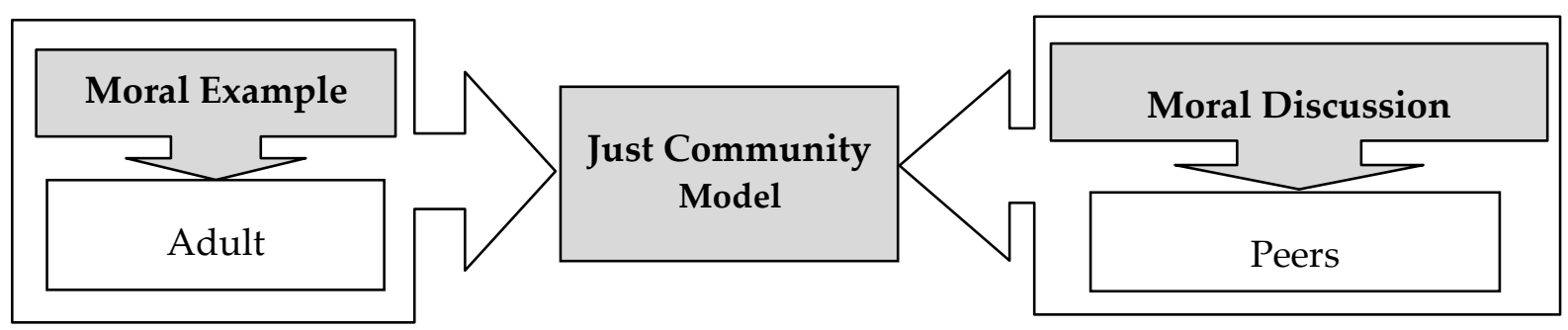

Figure 1. Just Community

In developing Just Community, Kohlberg used David Emile Durkheim's principles of collective socialization. This refers to cultural transmission where one learns the norms of their society and the notion of what to think, feel and do through instruction and explanation of role models and group assistance.

On the basis of moral socialization, character education is a social solidarity within group conformity and mutual support among members. According to Durkheim, social norms are the most effective control, not that they are socially imposed from the outside but because they are voluntarily internalized and function as "a living society within the individual"(Coser \& Rosenberg, 1964) (Dineen, 2019).

Durkheim states what applies at the wider community basis to be applied to a more narrow level like classes in school. In relation to moral education, Durkheim (Nucci et al., 2014)(Kurscheid et al., 2018) identifies three elements of morality. First was the spirit of discipline which include commendable and consistent behaviors, respect for social norms and authority, and other disciplinary behaviors. By setting 
clear rules and consequences, the child feels guided and monitored by the environment. The second, was interest in social groups and the spirit of altruism, stipulating that the unit of moral conduct and moral education is a group or society. Morality is a social or interpersonal activity within the unit of group and society. Selfish action is not considered a moral act. Third, autonomy or self-determination, where society is the highest authority for the children but following the rules of society is a must choice.

Just Community has two main objectives, producing moral development of children and changing the atmosphere of the school into a moral community (C. Power, 1988) (Farrell, 2019). Although the purpose of developing children's moral reasoning is the ultimate goal of the Just Community model, this objective is achieved by creating a conducive ethical atmosphere as a major target (F C Power \& Higgins, n.d.) (Mertasari, Yudana, Gita, \& Hapsari, 2019). The use of the model of moral development and student responsibility is driven through organization, practice, and culture of the school itself.

The Just Community consists of five main objectives, creating creativity and adaptation to the rules of all children; stimulating children's moral reasoning abilities; maintaining a balance between reasoning and action; training moral empathy and encourage pro-social commitment; and developing a solid value system based on forbearance and openness (F C Power \& Higgins, n.d.)(Kohlberg, Kauffman, Scharf, \& Hickey, 1975) (Natanasabapathy \& Maathuis-Smith, 2019). Good community culture such as relationship with others, norms, democratic and educational opportunities endorse character building of children (Dina Sukma Nurhizrah Gistituati,Daharnis Daharnis 4, 2018). This means Just Community also support character building of the student.

\section{How to Run Just Community Program?}

The Just Community model develops judgment and decision making through a practice called deliberative democracy. This process aims to achieve practical consensus through an ongoing dialogue in which all parties are encouraged to participate. The approach fosters a sense of responsibility by encouraging students to get acquainted with their group members as well as understanding moral values and through deliberation (F Clark Power \& Higgins-D'Alessandro, 2008).

The Just Community model is directed not only to promote the moral reasoning of children, but also to encourage all the components of the child to function (Narváez \& Rest, 1995) (Simonnet, Girard, Anquetil, Renault, \& Thomas, 2019). From the outset, the approach is understood as a bridge between consideration and moral action because it examines the real interaction amongst students and teachers at school. Just Community maintains moral sensitivity by bringing together issues of concern to the attention of teachers and students in their weekly meetings.

There are three types of meetings. First, small groups of learners and educators usually with a fifteenth upper limit meet to discuss issues of concern and aspiration such as theft, disruptive behavior, and so on (Fielding, 2013) (Brown et al., 2019). The involvement of such small groups leads to wiser and more interesting community meetings. It is also essential for the creation of a decent governance structure along with enhancing attachment to the community (Wasserman, 1982) (Pétré et al., 2019). Second, in some cases advisory group consisting of staff members with general counseling are required to meet. In some cases, students are taught peer counseling skills. While the main goal of a small group is to address community issues, the main function of the advisory class is to offer support on personal and academic matters. Thirdly, there is usually a meeting consisting of organizing committee, one of the community school research teams, interested staff, and students who accept the issues of small groups. Community meetings sometimes only receive views from different groups and make agenda decisions based on what they hear. More important, the reactive and proactive responses to the small group are informed by metalevel thinking which reviews previous community meetings, analyzes the current school functions from a theoretical point of view, suggests new ways to address emerging problems, develops skill staff, and the upcoming and understanding officials who clarify on moral issues. The third description of this meeting is summarized in Figure 2. 


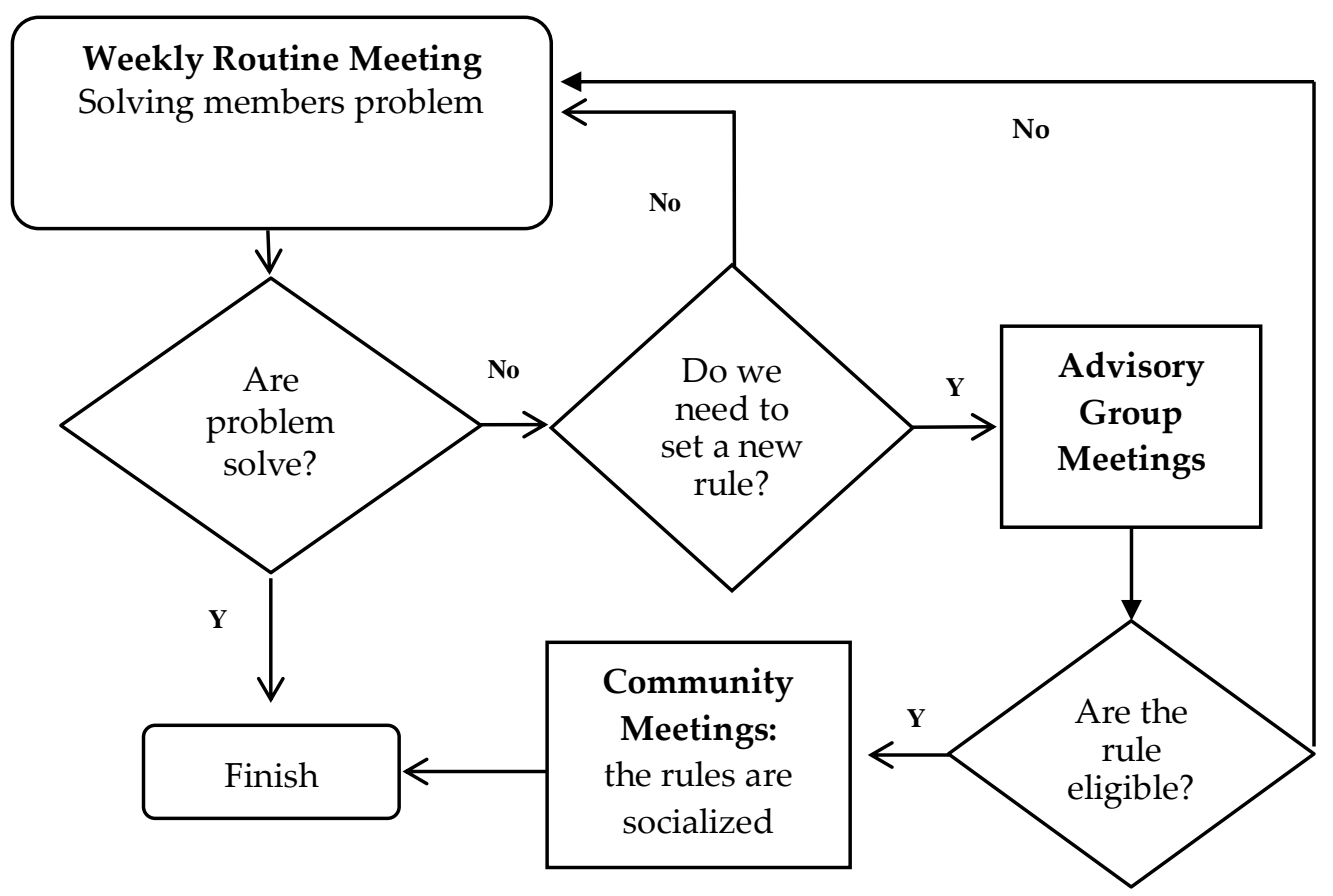

Figure 2. Just Community Program

Just Community brings into a group a hundred students and teachers for an hour or more each day for two weekly meetings for at least one hour of study. Most decisions affecting community life and discipline are made democratically in the weekly compulsory community meetings which students and teachers have the same voice. The members meet weekly in the advisory group to prepare for meetings. These programs are implemented with a strong commitment to develop a common moral life characterized by seeking justice and building group solidarity. Teachers in the Just Community program are challenged to demonstrate moral leadership in order to achieve common goals while engaging student.

In community meetings, students and teachers determine the rules and norms guiding their common life. Students and teachers are expected to help each other meet common expectations. When a violation occurs, a guilty party is brought before the whole community during the meeting. The Just Community model also encourages the implementation of the agreed-upon goal.

The agenda for community meetings should be discussed by small groups on various issues and try to reach consensus by majority and minority proposals brought to the next day's meeting. All these meetings serve as a context for moral discussion and achieve a sense of community solidarity. It helps to create a moral atmosphere through democratic governance practices (i.e, reaching fair decisions, implementing these decisions and, where necessary, changing their decisions democratically). Direct participatory democracy serves to protect the rights of students, and limits the power of group solidarity to impose the conceptions proposed.

Teachers, in regular classroom moral discussions, are facilitators, though in Just Community schools they are supporters of moral, justice and community content. Therefore, teachers serve as moral leaders by supporting their own views within one person, one voice and being involved with "what" the students decide to do as well as "why" they decide to do.

\section{What is the Aim of the Program?}

Barriers encountered in running Just Community hinder the accomplishment of Kohlberg these goals. Without attempting to denigrate the Just Community there are minimal moral purpose to be achieved (Oser, Althof, \& Higgins- D’Alessandro, 2008) (Mertasari et al., 2019). These include 
stimulating moral development at higher levels; making children and youth take action against more sensitive moral issues such as security, justice, honesty, tolerance, and provide a space to express moral feelings; supports and encourages moral behavior and pro-social; keep the moral atmosphere of the negative behavior; and provide opportunities for children to build knowledge of the ethics of actions, a reflection of the assessment of oneself and others. Just Community approach encourage the development of citizenship within a school or educational institution (F C Power \& Higgins, n.d.) (Yoon \& Armour, 2017). The citizenship is according to Westheimer and Kahne (F Clark Power \& Higgins-D'Alessandro, 2008) which consists of three types aspects, personally responsible, participatory, and oriented to justice.

There are four components of the culture of the school (school culture) used to measure the success of the Just Community Program. These include the relationships among students as well as with teachers, school norms, and democratic and educational opportunities (F Clark Power \& Higgins-D'Alessandro, 2008).

1. Relationship between students. An interaction with peers play an important role in the moral development of youth. Such a moral conception of justice, reciprocity, and well-being arises from social interaction and conflict of children with others. The main principle is through relationship and interactions with friends, the teen build understanding of morality (Piaget 1932/1965 in Hauser, Cushman, Young, Kang-Xing Jin, \& Mikhail, 2007) (Javidi \& Sheybani, 2019).

2. Relationship between students and the teachers. How teachers behave and act affect how students perceive and respond to them. If they look at teachers and respond positively it would be easier to internalize positive morals to them. The student perceives the rules as something that should be kept is the student award against the teacher.

3. Norms of the school. The school has rules and the code of conduct to be followed, such as praying at the start and end activities, respect to the teacher, follow lessons earnestly, polite association between students, keep clean, order, beauty, family, and school security.

4. Democratic and educational opportunities. Chance democratic means engaging students in the entire process of education, where they act as subjects rather than objects. Freedom for the students in question covers the right to work, develop the potential and argue, and the equation of students in education for there not to be a difference in degrees or dignity.

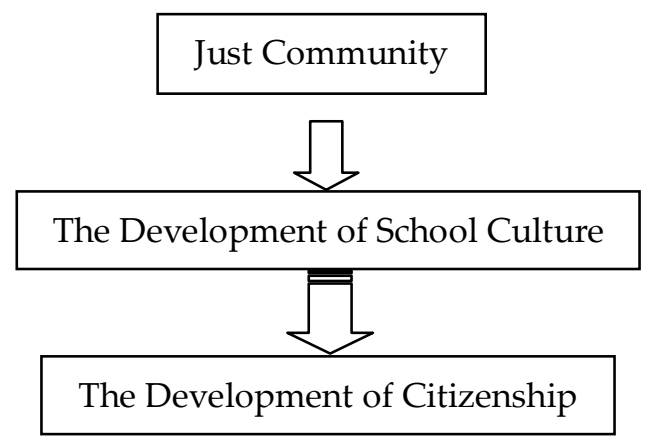

Figure 3. The Aim of Just Community Program

Just Community changes students by modifying their schools as described in Figure 3. Student involvement in making new rules changes the school culture by forcing principals, teachers, and other staffs to listen to students' aspirations. Just Community also change student through democratic program involving them in making new rule through change of community culture. Student involvement in making of rules helps them understand the importance of respecting the opinions of others and expressing their own views. This indicates they have absorbed the values of democracy. It also stimulate moral development at a higher stage of childhood. Childrens, especially adolescents are more sensitive to moral 


\section{COUNS-EDU}

Vol.4, No.1, 2019

Available online: http://journal.konselor.or.id/index.php/counsedu

Dina Sukma, et al.

issues such as security, justice, honesty, tolerance, and providing space for expressing moral feelings (Kowasch \& Lippe, 2019).

\section{Implication for Education}

Just Community stimulate ethical development of children and change the atmosphere of the school into a moral community. Although the purpose of developing children's moral reasoning is the ultimate goal of the Just Community model, this objective is achieved by creating a conducive moral atmosphere as a major goal (F C Power \& Higgins, n.d.) (Azorín, 2019). Using the model of moral development, student responsibility is driven through the organization, practice, and culture of the school itself.

The goal of Just Community consists of five main objectives are, creating creativity and adaptation to the rules of all children; stimulating moral reasoning abilities; maintain a balance between moral reasoning and action; training moral empathy and encourage pro-social commitment; and developing a solid value system based on tolerance and openness (F C Power \& Higgins, n.d.)(Kohlberg et al., 1975) (Fua, Wekke, Sabara, \& Nurlila, 2018). Good community culture such relationship with others, norms, democratic and educational opportunities endorse character building of children (Dina Sukma Nurhizrah Gistituati,Daharnis Daharnis4, 2018). This means Just Community also support character building of the student.

However, approaches based on school culture must be maintained. This is because shapes the character of students focusing solely on them regardless of how the culture encompasses them or their community is difficult. As John Dewey says, building students without developing their environment is a futile job or community culture that John Dewey calls a "hidden curriculum." Nevertheless, there are many obstacles faced in running the Just Community which Kohlberg's followers realized could inhibit the achievement of the goals formulated. The biggest challenge is the low level of school commitment to implement the program. However, the idea of fulfilling student "satisfaction" as part of school democracy are well-functioning educational democracy. Just Community has given a different color in building the character of students within school (Symeou \& Karagiorgi, 2018).

Previous research on Just Community shows there were significant changes in moral development and reasoning of children. Nonetheless, the implementation of Just Community is largely determined by the school's commitment to put it into practice, a difficult challenge to face. The school sometimes antipathy even refuses intervention from outside parties, making the research lose its appeal to other educational researchers. For example, the implementation of representative meetings (or advisory group meetings) if not managed properly lead to conflict which complicate matters. The aversion to something new is one of the obstacles in the application of Just Community in schools in general (Tan, 2019).

Developing a positive moral culture in schools does not mean the authority possessed by the coach must be abolished. This is a shared responsibility and must involve the entire community to give it a sense of democracy. This means each member of the school community has a responsibility to create a better life with others. For this reason, each individual is able to grow and develop with a sense of togetherness. Respect for individuals and a willingness to be actively involved in creating a better order of shared life is a sign that democratic values are appreciated. Dialogue and communication means willingness to listen to each other and appreciate diversity, the basic characteristics of a democratic society.

\section{Conclusions}

Just Community stimulate moral development at a higher stage of children. Childrens and adolescents more sensitive to moral issues such as security, justice, honesty, tolerance and providing space for expressing moral feelings. But, there are many obstacles faced in running the Just Community that Kohlberg' s followers realize can inhibit achieve the goals that have been planned. The biggest obstacle is the low level of school commitment to implement the program. However, fulfill student "satisfaction" being part of school democracy are well-functioning educational democracy. Just Community has given a different color in building the character of students in school. 


\section{References}

Aldridge, D. (2019). Reading, engagement and higher education. Higher Education Research and Development, 38(1), 38-50. https://doi.org/10.1080/07294360.2018.1534804

Azorín, C. (2019). The emergence of professional learning networks in Spain. Journal of Professional Capital and Community, 4(1), 36-51. https://doi.org/10.1108/JPCC-03-2018-0012

Bates, A. (2019). Character education and the "priority of recognition." Cambridge Journal of Education. https://doi.org/10.1080/0305764X.2019.1590529

Brown, J., Bearman, M., Kirby, C., Molloy, E., Colville, D., \& Nestel, D. (2019). Theory, a lost character? As presented in general practice education research papers. Medical Education, 53(5), 443-457. https://doi.org/10.1111/medu.13793

Coser, L. A., \& Rosenberg, B. (1964). Social Theory. New York: The mAcMillan Company.

Dina Sukma Nurhizrah Gistituati,Daharnis Daharnis4, A. A. (2018). Community Culture and Character: Correlational Study of Youth Offender in Child Prison. Fakultas Ilmu Pendidikan PP - Padang. https://doi.org/https://doi.org/10.29210/2018117

Dineen, K. (2019). Kant, emotion and autism: towards an inclusive approach to character education. Ethics and Education, 14(1), 1-14. https://doi.org/10.1080/17449642.2018.1505150

Farrell, A. (2019). SWIFT beginnings-exploring the effectiveness and transformative character of a Summer Writing Institute For Teachers (SWIFT). Innovations in Education and Teaching International, 56(2), 229-238. https://doi.org/10.1080/14703297.2017.1412833

Fielding, M. (2013). Whole school meetings and the development of radical democratic community. Studies in Philosophy and Education, 32(2), 123-140.

Fua, J. L., Wekke, I. S., Sabara, Z., \& Nurlila, R. U. (2018). Development of Environmental Care Attitude of Students through Religion Education Approach in Indonesia. In IOP Conference Series: Earth and Environmental Science (Vol. 175). https://doi.org/10.1088/1755-1315/175/1/012229

Hauser, M., Cushman, F., Young, L., Kang-Xing Jin, R., \& Mikhail, J. (2007). A dissociation between moral judgments and justifications. Mind \& Language, 22(1), 1-21.

Javidi, G., \& Sheybani, E. (2019). K-12 Cybersecurity Education, Research, and Outreach. In Proceedings Frontiers in Education Conference, FIE (Vol. 2018-October). https://doi.org/10.1109/FIE.2018.8659021

Kohlberg, L., Kauffman, K., Scharf, P., \& Hickey, J. (1975). The just community approach to corrections: A theory. Journal of Moral Education, 4(3), 243-260.

Kowasch, M., \& Lippe, D. F. (2019). Moral impasses in sustainability education? Empirical results from school geography in Austria and Germany. Environmental Education Research. https://doi.org/10.1080/13504622.2018.1557112

Kurscheid, J., Bendrups, D., Susilo, J., Williams, C., Amaral, S., Laksono, B., ... Gray, D. J. (2018). Shadow puppets and neglected diseases: Evaluating a health promotion performance in rural Indonesia. International Journal of Environmental Research and Public Health, 15(9). https://doi.org/10.3390/ijerph15092050

Kuznetsova, O. N., Maksimov, V. Y., Narozhnaya, G. A., Tkachenko, A. E., \& Toiskin, V. S. (2019). Approaches to quality of education that conform to the needs of labor market in information society. Advances in Intelligent Systems and Computing. https://doi.org/10.1007/978-3-319-90835-9_128

Lind, G., \& Althof, W. (1992). Does the Just Community experience make a difference? Measuring and evaluating the effect of the DES project. In Moral education forum (Vol. 17, pp. 19-28).

Mertasari, N. M. S., Yudana, M., Gita, N., \& Hapsari, R. (2019). Using the Environment as a Workshop for Vocational Education. In Journal of Physics: Conference Series (Vol. 1165). https://doi.org/10.1088/1742-6596/1165/1/012016

Narváez, D., \& Rest, J. (1995). The four components of acting morally. Moral Behavior and Moral Development: An Introduction, 385-400.

Natanasabapathy, P., \& Maathuis-Smith, S. (2019). Philosophy of being and becoming: A transformative learning approach using threshold concepts. Educational Philosophy and Theory, 51(4), 369-379. 
https://doi.org/10.1080/00131857.2018.1464439

Nucci, L., Krettenauer, T., \& Narváez, D. (2014). Handbook of moral and character education. Routledge.

Oser, F. K., Althof, W., \& Higgins-D'Alessandro, A. (2008). The Just Community approach to moral education: system change or individual change? Journal of Moral Education, 37(3), 395-415.

Pétré, B., Peignot, A., Gagnayre, R., Bertin, E., Ziegler, O., \& Guillaume, M. (2019). The educative posture, a cornerstone in the service of therapeutic patient education! . Education Therapeutique Du Patient, 11(1). https://doi.org/10.1051/tpe/2018019

Power, C. (1988). The just community approach to moral education. Journal of Moral Education, 17(3), 195208.

Power, F. C., \& Higgins-D'Alessandro, A. (2008). The just community approach to moral education and the moral atmosphere of the school. Handbook of Moral and Character Education, 230-247.

Power, F. C., \& Higgins, A. (n.d.). L. KOHLBERG,(1989): Lawrence Kohlberg's Approach to Moral Education. New York, Columbia University Press.

Sarason, S. B. (1974). The psychological sense of community: Prospects for a community psychology. Jossey-Bass.

Simonnet, D., Girard, N., Anquetil, E., Renault, M., \& Thomas, S. (2019). Evaluation of children cursive handwritten words for e-education. Pattern Recognition Letters, 121, 133-139. https://doi.org/10.1016/j.patrec.2018.07.021

Snarey, J. R., Reimer, J., \& Kohlberg, L. (1985). Development of social-moral reasoning among Kibbutz adolescents: A longitudinal cross-cultural study. Developmental Psychology, 21(1), 3.

Stichter, M., \& Saunders, L. (2019). Positive psychology and virtue: Values in action. Journal of Positive Psychology, 14(1), 1-5. https://doi.org/10.1080/17439760.2018.1528381

Symeou, L., \& Karagiorgi, Y. (2018). Culturally aware but not yet ready to teach the "others": Reflections on a Roma education teacher training programme. Journal for Multicultural Education, 12(4), 314-329. https://doi.org/10.1108/JME-02-2017-0012

Tan, C. (2019). Mencius' extension of moral feelings: implications for cosmopolitan education. Ethics and Education, 14(1), 70-83. https://doi.org/10.1080/17449642.2018.1538690

Wasserman, I. M. (1982). Size of place in relation to community attachment and satisfaction with community services. Social Indicators Research, 11(4), 421-436.

Wren, D. J. (1999). School culture: Exploring the hidden curriculum. Adolescence, 34(135), 593.

Yoon, K., \& Armour, K. M. (2017). Mapping physical education teachers' professional learning and impacts on pupil learning in a community of practice in South Korea. Physical Education and Sport Pedagogy, 22(4), 427-444. https://doi.org/10.1080/17408989.2016.1268589 